\title{
“Coser y desgarrar, conservar y arrojar". Visiones del enemigo y estrategias de supervivencia psíquica en la División Azul
}

\author{
David Alegre LoRENZ \\ Universitat Autònoma de Barcelona \\ david.alegre.lorenz@gmail.com
}

Recibido: 01/05/2012

Aceptado: 20/07/2012

\section{RESUMEN}

El artículo propone una reconstrucción de los temores y marcos de referencia del combatiente fascista de la División Azul, todo ello por medio del análisis del lenguaje desde una perspectiva psicoanalítica. De algún modo, el objetivo es observar cómo se produce el proceso de identificación del enemigo y la desempatización que hicieron posible el despliegue de una extremada brutalidad en el combate. En este sentido, veremos cómo se produce una identificación absoluta entre los rusos (civiles y combatientes), el comunismo, el judaísmo y el paisaje. Tanto es así, que el combatiente fascista vive bajo una sensación permanente de cerco. En última instancia, observamos que el fascista enfrenta dicha amenaza al tiempo que huye de ella en un incontenible impulso violento entendido como acto de fe.

Palabras clave: Fascismo, violencia fascista, alteridad, análisis del lenguaje, Segunda Guerra Mundial.

\section{"Sewing and Tear, Keep and Throw". Visions of the Enemy and Psychical Strategies of Survival in the Blue Division}

\begin{abstract}
This article analyzes the fears and projections of the Spanish fascist soldier in the Blue Division, all through the analysis of language from a psychoanalytic view. In some way, the aim is to understand how the enemy is seen and how is produced the process of contempt toward the enemy that made possible the deployment of an extreme brutality in combat. In this sense, we'll see an absolute correspondence among the Russian people (civilians and soldiers), Communism, Judaism and the landscape. So much so that the fascist soldier lives under a permanent feeling of siege. At last, we can see how the fascist face this threat at the same time that he avoids it running away in a violent drive understood as act of faith.
\end{abstract}

Key words: Fascism, Fascist Violence, Otherness, Analysis of Language, Second World War.

Sumario: Introducción. 1. Algunas visiones del comunismo y su identificación con Rusia. 1.1. Comunismo y judaísmo. El antisemitismo en el fascismo español. 1.2. La agorafobia fascista y las oleadas de rusos que brotan de la tierra. 1.3. Otros peligros y amenazas: el abismo interno del ego fascista, la retaguardia como espacio de subversión, el traidor y el cobarde. 2. El derribo de las misteriosas puertas de lo imposible o la huida hacia delante. 3. Conclusiones. El fascismo: una utopía quijotesca. 


\section{Introducción}

Para la realización de este artículo partimos de un trabajo anterior, El fascismo como experiencia interna somatizante ${ }^{1}$, donde ya empleamos como fuente fundamental memorias de veteranos de la División Azul y otros textos relacionados con dicha unidad militar. Al igual que entonces, nuestro objetivo no es otro que aproximarnos a la conciencia e identidad fascistas españolas en un entorno privilegiado para su despliegue como fue el del Frente del Este durante la Segunda Guerra Mundial, en este caso dentro de esta división española de voluntarios encuadrada en la Wehrmacht. Cabe decir que en líneas generales seguimos suscribiendo las tesis fundamentales defendidas en el artículo anteriormente referido, de forma que lo que aquí nos proponemos es profundizar en algunas de ellas.

De algún modo, creemos que las experiencias de combate y su posterior plasmación "deformada" sobre el papel en forma de memorias van a estar muy definidas por el binomio destrucción-creación o, parafraseando a Döblin, por el desgarro y el hilado de la realidad como medio para la conservación del ego maltrecho por los traumas de la guerra y la derrota. Así, como trataremos de demostrar, suscribimos la idea de que las palabras y los hechos serían inseparables dentro del fascismo -siendo aquéllas una proyección de éstos y viceversa-, que observamos como una forma de posicionarse ante la realidad, como una actitud frente a la vida nacida de unas circunstancias históricas particulares. Ya a la altura de 1933, el primer y único número de la revista El Fascio apuntaba en este sentido al afirmar que "Para ser fascista no es necesaria ninguna credencial ni ningún carnet. Basta sentirlo, y hacérselo sentir al que se tenga cerca. Después, cuando la organización surja, cada cual encontrará su puesto." ${ }^{2}$ No por nada, Klaus Theweleit apuntaba claramente en la línea de que el fascismo no responde tanto a un problema de miseria económica o desempleo como a una profunda necesidad de índole psicológica, tal y como trataremos de explicar. Al mismo tiempo, criticaba la escasez de miras de los análisis estrictamente materialistas que durante mucho tiempo han marcado a amplios sectores de la historiografía y la política ${ }^{3}$.

Precisamente, este trabajo se fundamenta en los aportes de este filólogo alemán, concretamente en su metodología de análisis del lenguaje desde una perspectiva psicoanalítica, siempre con la vista puesta en la comprensión de las dinámicas internas del fascista. A partir de los debates mantenidos con otros historiadores extraemos la idea de la existencia de una herencia cultural muy relacionada con algunas características fundamentales de nuestra cultura judeo-cristiana, de la cual los fascismosmovimiento de Entreguerras extraerían no pocos de sus elementos definitorios ${ }^{4}$. En buena medida, partimos de las tesis de Roger Griffin, quien precisamente entiende

1 ALEGRE LORENZ, David: "El fascismo como experiencia interna somatizante: una propuesta de análisis del fascismo español a través del lenguaje", en Miguel Ángel RUÍZ CARNICER (ed.): Falange. Las culturas políticas del fascismo en la España de Franco, Zaragoza, PUZ e IFC, 2012, en prensas.

2 El Fascio. Haz Hispano, no 1, 16 de marzo de 1933, p. 15.

3 THEWELEIT, Klaus: Male Fantasies. Volume 1: Women, Floods, Bodies, History, Minneapolis, University of Minnesota Press, 2007 (sexta edición), p. 432.

4 Precisamente nos referimos a él como fascismo cultural, que de uno u otro modo seguiría teniendo un protagonismo muy significativo en múltiples aspectos de nuestras vidas, tanto a nivel individual como colec- 
que este fenómeno no nació ex nihilo, sino que fue el producto de un clima políticocultural y socio-económico muy concretos -algunos de ellos de muy largo alcance-. Precisamente, compartimos los planteamientos del historiador inglés, quien defiende que el fascismo podría identificarse, entre otras cosas, con el deseo de construir un nuevo mundo por medio de la destrucción dada la creencia de estar ante el fin de una época, lo cual justificaría el despliegue de una violencia radical de tonos apocalípticos y mesiánicos. ${ }^{5}$ Por lo tanto, creemos que el fenómeno en cuestión tendría una dimensión psicológica y emocional clave, como bien demuestra José María Sánchez Diana, veterano de la División Azul, quien afirmara que

El soldado español es de los mejores del mundo, pero siempre que le den posibilidades de desplegar el tesoro de su carácter. Los entorchados no son nada si no se saben respetar. Lo mismo en la política. No necesitamos la democracia, la llevamos en el corazón, pero a cambio exigimos respeto. Nada de reglamentos, leyes escritas u ordenanzas como esas tonterías de la época de Carlos III que siguen aprendiéndose en las academias y cuarteles. Por encima de estas páginas anacrónicas, tiene que haber el entendido perfecto que necesita una base psicológica y voluntarista... solo así harán de nosotros lo que se quiera. ${ }^{6}$

De algún modo, podemos ver cómo el propio fascista nos está ofreciendo la clave para la comprensión del fenómeno propiamente dicho, desde lo que es a lo que el individuo busca en éste, es decir, protección a través de toda una serie de elementos para relacionarse con las diferentes dimensiones de la realidad, tanto la interna propia como la externa. De hecho, si lo preferimos, el fascismo no sería tanto una serie de normas y códigos morales -aunque hay mucho de tácito en él- como una apelación al "espíritu" , de forma que extraería todo de los hombres por medio de su capacidad para canalizar sus impulsos y proyecciones internas de forma ordenada. Así, la democracia del fascista vendría a ser esa capacidad para sentir junto a "los suyos" una comunión de impulsos dirigidos por diferentes medios hacia unos determinados objetivos. Su éxito radica en esa capacidad para apelar a algo que está más allá de las condiciones materiales objetivas, es decir, algo permanente y trascendental y, al mismo tiempo, para hacer creer a multitud de individuos que es lo que ellos creen que es o debería ser o, dicho de otro modo, que responde a sus necesidades más profundas.

Antes de plantear la tesis que va a servir de guía a este artículo cabe plantear algunas precisiones más. En primer lugar hay que señalar la necesidad de descender al caso individual para comprender la naturaleza, motivaciones y modus operandi del fascista, quizás de este modo consigamos aproximarnos a algún tipo de respuesta en preguntas como qué es el fascismo, cómo identificarlo y qué aporta al hombre. En

tivo: obsesión por la unidad y el orden, violencia de género, miedo a la disolución, rechazo de puntos de vista diferentes, etc.

5 GRIFFIN, Roger: Modernismo y fascismo. La sensación de comienzo bajo Mussolini y Hitler, Madrid, Akal, 2010, pp. 256-257.

6 SÁNCHEZ DIANA, José María: Cabeza de puente. Diario de un soldado de Hitler, Alicante, García Hispán Editor, 1990, p. 212. La cursiva es mía.

7 Lo que el fascista entendería como tal, es decir, el lado místico-poético o trascedente del ego, el nos y el entorno en que se enmarca su existencia. 
segundo lugar nos parece importante destacar que concebimos el fascismo como una consecuencia de la modernidad, muy relacionado por lo tanto con el auge del relativismo y la subjetividad traídos por ésta y, por lo tanto, con el intento por restituir toda una serie de valores absolutos y permanentes que faciliten la relación del individuo con la realidad externa a él. Precisamente por ello, en tercer lugar, creemos necesario apuntar que en última instancia el fascista se forja en la incapacidad para resolver la contradicción existente entre unos valores individuales concretos -es decir, aquellos defendidos por un sujeto- y los de la sociedad moderna en su conjunto, caracterizado por su naturaleza poliédrica y polifónica. De esta disonancia traumática para el individuo surge el sujeto fascista, es decir, de la incapacidad para relacionar de forma natural el ego con el ello. En este sentido, la tensión llega hasta tal punto que en dicha relación se acaban imponiendo toda una serie de mecanismos represivos que Theweleit ha definido metafóricamente como body armor, que limitaría en la medida de lo posible toda influencia desordenada del ego sobre la realidad externa y viceversa, con el objetivo de conjurar cualquier amenaza de disolución. Lo que ofrecerían el fascismo movimiento y el estado fascista serían diferentes sistemas de canalización de los impulsos contenidos dentro de dicha armadura corporal y, al mismo tiempo, un entorno socio-cultural y político seguro para el desenvolvimiento del individuo. Aquí nos encontramos con la razón última de la lógica interna del fascismo: la huida constante hacia delante, que a menudo conduce a la autodestrucción del individuo y del estado y sociedad fascistas, precisamente por el recurso continuado a la violencia como principal instrumento canalizador de esos impulsos reprimidos. De ahí que la guerra sea una dimensión fundamental de este fenómeno y una atalaya privilegiada para la comprensión de su lógica y dinámicas internas, como de hecho ha apuntando Javier Rodrigo en los últimos tiempos ${ }^{8}$. Justamente por ello, Robert Paxton sostenía que entre otras cosas el fascismo se sostenía sobre la promesa de una supuesta resolución a la crisis de la modernidad, que precisamente se basaba en la idea de una "revolución permanente" fundamentada en el recurso a la violencia, la cual ocuparía un lugar central ${ }^{9}$. Esa necesidad constante de dinamismo llevó al fascismo a una constante huida hacia delante, todo ello en la ilusión y necesidad de mantener una relación privilegiada con la historia que legitimara al fenómeno como tal. No por nada, muchos de los voluntarios europeos -entre ellos los españoles- marcharon a Rusia movidos por dicha conciencia.

Con la guerra, el fascismo se jugaba el todo por el todo, tanto a nivel individual como a nivel colectivo. No solamente se trataba de la confluencia de múltiples proyectos políticos, como podría ocurrir en los casos paradigmáticos de Ridruejo o Sotomayor en la División Azul, con una visión muy personal de lo que habría de ser la España fascista, sino que de algún modo estaríamos ante un acto de fe personal dirigido a restituir una suerte de dosel sagrado perdido: la lucha contra el comunismo, la españolidad, el catolicismo, la frontgemeinschaft, la civilización europea, el deseo de trascendencia, la simple búsqueda de respuestas, la violencia como acto estético,

8 RODRIGO, Javier: "Violencia y fascistización en la España sublevada" en Francisco MORENTE: España en la crisis europea de entreguerras, Madrid, Los Libros de la Catarata, 2011, pp. 79-95.

9 PAXTON, Robert O.: Anatomía del fascismo, Barcelona, Península, 2005, p. 175. 
etc. ${ }^{10}$ Por lo tanto, la guerra ofrecería el ecosistema donde el fascismo se desenvolvería en toda su expresión, produciéndose por medio de la violencia la relación del ego con el ello, al tiempo que éste sería reconfigurado a través del impulso destructivo y creativo de aquél. Lo que en no poca medida haría posible esa violencia sería el hecho de que el fascista observe la realidad externa como algo amenazador y potencialmente subversivo que identifica con aquello que porta en su interior y de lo cual huye: sus propios impulsos internos.

A partir de la lectura y análisis de las memorias de veteranos de la División Azul creemos encontrar justificado un enfoque del mundo interno del soldado fascista que parta precisamente del análisis del lenguaje, algo que a menudo pasa desapercibido para la historiografía, una muestra más de las múltiples dificultades existentes para tomar en serio el fascismo. En sí mismo, el acto de escribir implica un moldeamiento y, por qué no, apropiación de la realidad a imagen y semejanza del escritor, de forma más destacada si cabe cuando se trata de textos de tipo memorístico o autobiográfico. En el caso del fascista, el objetivo no sería otro que restañar el ego y el nos -por los potenciales lectores- maltrechos por la derrota y el trauma de la guerra. Para ello se sirven de un estilo sencillo que apela a lo heroico y se remite constantemente a toda una serie de lugares comunes que se repiten de forma sorprendente en diferentes textos y autores; de hecho, si por algo se caracteriza el fascista es por expresarse con gran plasticidad, buscando producir en el lector las mismas reacciones psicosomáticas que se dan en él al escribir o que se dieron en él al vivir las experiencias referidas. Una vez más, la clave la encontramos en Sánchez Diana, quien afirma que

Decimos Padre Nuestro que estás en los Cielos y sin darnos cuenta, soltamos esta gigantesca afirmación. ¿Por qué no nos fijamos un poco más en las palabras? Quizás porque hablamos demasiado. ¿Nos damos cuenta de que las palabras son importantísimas?. Madre, me voy a la guerra. Así de fuerte y de suficiente. ${ }^{11}$

\section{Algunas visiones del comunismo y su identificación con Rusia}

Uno de los lemas que dominó la campaña de alistamiento a la División Azul desde el verano de 1941 fue la famosa frase de tres palabras pronunciada por Serrano Suñer, precisamente en medio de un discurso enardecedor que dirigió a los decenas de miles de hombres congregados bajo los balcones de la Secretaría General del Movimiento de Madrid para solicitar la entrada de España en la guerra. Aquel caluroso 24 de junio, con la invasión alemana de la URSS en marcha desde hacía dos días, Suñer, asesorado por Dionisio Ridruejo, acuñó aquellas tres palabras que iban a tener una amplia resonancia a nivel nacional y que resultan harto significativas: " $i R u s i a$ es culpable!", a lo cual cabría añadir la no menos significativa idea de que "El exterminio

10 Razones que encontraríamos junto a otras no menos importantes como la promesa de una buena paga, el rancho diario, la necesidad de purgar pasados familiares dudosos, los voluntarios forzados o el deseo de aventuras.

11 SÁNCHEZ DIANA, José María: Cabeza de puente..., p. 31. La cursiva es mía. 


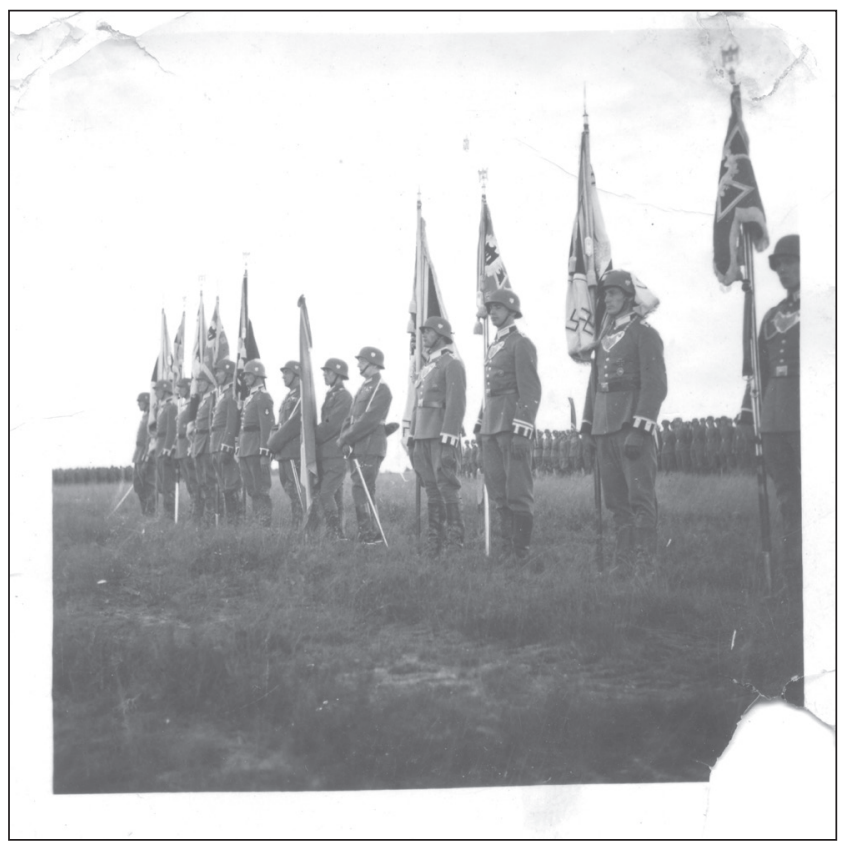

Juramento a la bandera alemana y a Hitler. Archivo Rodríguez Jiménez

de Rusia es exigencia de la historia y del porvenir de Europa." ${ }^{12}$ Desde nuestro punto de vista no se han llegado a medir en toda su magnitud las implicaciones inherentes a este discurso, que no hace sino poner de manifiesto uno de los problemas -o ventajas, si lo miramos desde el punto de vista de las necesidades de la guerra- con los que se van a encontrar los combatientes de la División Azul: la dificultad para distinguir entre rusos y comunistas, entre Rusia y el comunismo propiamente dicho. De hecho, ambas ideas van a ser plenamente asociadas, convirtiéndose en un mecanismo legitimador de políticas de ocupación marcadas por los excesos ${ }^{13} \mathrm{y}$, al mismo tiempo, por el despliegue de una tremenda brutalidad en el combate. No por nada, el propio Sánchez Diana se hacía eco de este curioso oxímoron, lo cual no deja de ser significativo en alguien que llegó a interiorizar las dinámicas inherentes a esta lógica hasta el punto de servirse de ella como subterfugio para justificar su proceder como combatiente durante su estancia en el Frente del Este. Así pues, recordaba como un compañero le decía que «aquí $[. .$.$] venimos a [. .$.$] destruir una idea... la comunista».$ Esto llevó al autor a plantearse la siguiente reflexión:

12 Véase REVERTE, Jorge M.: La División Azul. Rusia, 1941-1944, Barcelona, RBA, 2011, p. 54.

13 Más allá del mito divisionario cultivado por los veteranos a lo largo de los años posteriores a la vuelta a España, según el cual sus relaciones con los rusos habrían estado marcadas por la cordialidad. Una línea interpretativa que integra multitud de voces y que, además, viene a desmentir los tópicos anteriormente referidos es la de NÚÑEZ SEIXAS, Xosé Manoel: “¿Eran los rusos culpables? Imagen del enemigo y políticas de ocupación de la División Azul en el Frente del Este, 1941-1944". Hispania. Revista Española de Historia, 223 (2006), vol. LXVI, pp. 695-750. 
No me quedó muy aclarada la cosa cuando le planteo que hay una diferencia entre Rusia misma y la idea comunista. Bien está que vengamos a luchar contra el marxismo pero la Historia y el paisaje de Rusia son otra cosa. $[\mathrm{Sic}]^{14}$

De hecho, más allá de sus evidentes motivaciones políticas, la idea de los impulsores de la División Azul está clara: se trata de dar una resolución definitiva al problema del comunismo, que en este caso se solapa con Rusia o aparece enmarcado por ésta. Se trata de atacarlo de raíz, una idea muy del gusto del fascismo ${ }^{15}$. Así, como ya venimos apuntando, se produce una construcción del enemigo en base a la asociación indisoluble entre Rusia y el comunismo. De hecho, esta va a ser una idea que va a encontrar un campo bien abonado debido al trabajo propagandístico desplegado por los golpistas desde 1936, de acuerdo con el cual Rusia estaría detrás de las desgracias acontecidas en España desde $1931^{16}$. Santos Juliá apunta que el modo de entender el comunismo entre amplios sectores de la derecha española y el ejército se levantó desde los años 20 sobre experiencias y reflexiones autóctonas, asentándose por tanto en una cultura política propia. ${ }^{17}$

Como vemos, queda bastante claro que el juego de marcos de referencia que permitió el envío de una división de voluntarios para participar en la guerra que Alemania sostenía contra la Unión Soviética estaba plenamente consolidado, lo cual, al mismo tiempo, nos da una explicación bastante coherente del éxito inicial en la campaña de alistamientos y en las movilizaciones que rodearon a éstos. De hecho, como apuntábamos, el propio Sánchez Diana, capaz de observar la contradicción inherente a este juego de asociaciones cerradas entre Rusia y el comunismo, no estará exento de caer en ella a la hora de justificar algunos de los comportamientos salvajes de sus compañeros de armas, como ocurre cuando habla del sargento Filiberto, del cual afirma que "Todos los prisioneros que coge se los carga. En España perdió a su padre asesinado cuando en el pueblo se enteraron que el hijo luchaba a las órdenes de Yagüe. No perdona, [...]." ${ }^{18}$ Así, podemos ver cómo el excombatiente percibe una relación directa entre lo ocurrido en España entre 1936 y 1939 y la existencia del comunismo soviético en el mundo. En la mayor parte de las memorias o autobiografías de los excombatientes observamos reflexiones y motivaciones similares en torno a este hecho. De hecho, otro ejemplo significativo es el de Juan Chicharro Lamamié de Clairac, quien apuntaba sin entrar en especificaciones que "No quiero describir aquí

14 SÁNCHEZ DIANA, José María: Cabeza de puente..., p. 90.

15 Para el caso de la guerra civil, periodo formativo de la conciencia e identidad fascista españolas con un papel decisivo de la violencia véase RODRIGO, Javier: Hasta la raíz. Violencia durante la Guerra Civil y la dictadura franquista, Madrid, Alianza, 2008.

16 Me parece interesante traer a colación las palabras de Teodoro Palacios, capitán de la División Azul, quien hace un balance de los años republicanos en los siguientes términos: «En el verano de 1936, estando en Potes, nos llegó la noticia de que Calvo Sotelo, el jefe de la minoría monárquica, había sido asesinado por orden del Gobierno procomunista. Se rumoreaba y se decía que el Ejército estaba a punto de rebelarse contra el estado de anarquía que vivía España.» LUCA DE TENA, Torcuato: Embajador en el infierno, Barcelona, Planeta, 1991, p. 39. La cursiva es mía. Podemos ver una vez más la mano negra de la URSS tras los sucesos del 36 y la identificación del estado de España con la máxima forma de disolución concebida por el fascista (y por lo tanto la más amenazadora): la anarquía.

17 JULIÁ, Santos: "Las nombres de la guerra", Claves de razón práctica, 164 (2006), p. 30.

18 SÁNCHEZ DIANA, José María: Cabeza de puente..., p. 112. 
la emoción tan grande que nos embargaba a Antonio y a mí: poder luchar contra el comunismo que tanto daño había hecho a España y a mi familia."19

\subsection{Comunismo y judaísmo. El antisemitismo en el fascismo español}

Este punto nos parece particularmente interesante por el hecho de que tiende a aceptarse desde amplios sectores de la historiografía la ausencia de un componente antisemita en el fascismo español, algo natural partiendo del hecho de que la mayor parte de los expertos ni tan siquiera ven en la dictadura franquista un régimen de naturaleza fascista ${ }^{20}$. Sea como fuere, lo cierto es que en la visión propia del fascista el comunismo y el judaísmo van de la mano, siendo ambos la máxima expresión del peligro de disolución contra el que combate aquél. Sin ir más lejos, Theweleit planteaba que

Fascism, then, waged its battle against human desires by encoding them with a particular set of attributes: with effeminacy, unhealthiness, criminality, Jewishness -all of which existed together under the umbrella of "Bolshevism.".21

De hecho, es sorprendente ver hasta qué punto se asemeja en este punto el sentir del fascista español al del alemán, que es el caso analizado por Theweleit. Vemos por ejemplo un artículo de la Hoja de Campaña en el que Enrique Blanco B. afirma que

El verdadero enemigo [...] aunque disfrace sus reales fines en un carnaval absurdo y trágico como el de las máscaras de antaño, podemos decirle: jte conocemos! Son tus apellidos Democracia, Marxismo y Plutocracia, pero tu nombre de pila es inconfundible: te llamas judaísmo. ${ }^{22}$

Quizás podría aducirse que este fenómeno es un producto de la "aculturación" de los voluntarios integrados en la Wehrmacht y, por lo tanto, marcados por un contacto relativamente intenso con el nacionalsocialismo y la Alemania de la época ${ }^{23}$, pero sin lugar a dudas hay una herencia cultural propia que hace posible la asimilación y creación autóctona de este tipo de marcos de referencia. Precisamente, esta es la tesis que defiende Núñez Seixas. ${ }^{24}$

Merece la pena dar al lenguaje la importancia que tiene en el caso del fragmento de la Hoja de Campaña referido un poco más arriba, de hecho no se puede despreciar

19 CHICHARRO LAMAMIÉ DE CLAIRAC, J.: Diario de un antitanquista en la División Azul, Madrid, Fundación División Azul, 2001, p. 13.

20 También se aduce muy menudo el reducido tamaño de la comunidad judía residente en España, 5000 según las listas de la Conferencia de Wannsee, que a su vez se basaban en las estadísticas de las autoridades españolas.

21 THEWELEIT, Klaus: Male Fantasies. Volume 2 Male Bodies: Psychoanalyzing the White Terror, Minneapolis, University of Minnesota Press, 1989, p. 13.

22 Hoja de Campaña, n 26, 4 de mayo de 1942.

23 Estos aspectos han sido tratados por NÚNNEZ SEIXAS, Xosé Manoel: "El Tercer Reich, la Wehrmacht y la División Azul". Ayer, 69 (2008), pp. 47-72.

24 NÚÑEZ SEIXAS, Xosé Manoel: “¿Testigos o encubridores? La División Azul y el Holocausto de los judíos europeos: entre historia y memoria”, Historia y Política, 26 (2011), p. 260. 
un texto así como mera retórica, porque lo cierto es que palabras así están dirigidas a dar con una reacción concreta entre sus destinatarios: la rigidez como método de protección y la violencia como respuesta. De algún modo, existe la creencia de que esas categorías como "Marxismo", "Plutocracia" o "judaísmo" tienen su existencia como entes encarnados que suponen una verdadera amenaza para la integridad del individuo y ello provoca un inmenso terror. Sin embargo, lo cierto es que en muchos casos la imagen que se construye del soldado ruso a posteriori es poco menos que la de un pobre desgraciado engañado o sometido por un ente poco definido como sería el comunismo, que no obstante va a ser antropomorfizado y dotado de vida propia en su capacidad para alienar al individuo.

El Ejército Rojo, afirmaba un capellán divisionario ya en 1942, no sería más que una colección informe de "hambrientos y engañados hijos del pueblo ruso, sacrificados por la locura, el orgullo y la maldad de sus dirigentes judeo-masónicos". ${ }^{25}$

En muchos casos esto va a llegar hasta el punto de que algunos veteranos van a exculpar al ruso por el comunismo, llegando a reconocerle sus virtudes como soldado. Sin embargo, es importante tener en cuenta que la mayor parte de estas visiones serán construidas a posteriori, tanto es así que en casos como el de Sánchez Diana, quien muestra con particular crudeza y sinceridad las visiones e ideas que dominaban a los divisionarios, podemos ver hasta qué punto muchos de los excombatientes reelaboraron su experiencia en clave "buenista", corriendo un tupido velo sobre diversas cuestiones que con el tiempo acabarían siendo vistas como incómodas. Un ejemplo curioso donde aflora el antisemitismo cultural es traído a colación por el propio Sánchez Diana, quien pone en boca de un compañero de armas andaluz la siguiente frase: "Ozú, que frío vamos a pasá en esta encabronada tierra de judíos [Sic]"; sin embargo, un episodio más curioso aún si cabe lo encontramos durante la convalecencia del autor en Königsberg, donde recuerda que

había dos españoles nada mas, una chica y un mallorquín llamado Roselló que poseía una tiendecilla de frutas llamada "Spanisch Garten". [...] el muy frescales, cobraba lo que quería. [...] Para mí, era un judío mallorquín y le conocíamos bajo el nombre de "chueta", lo que a él le daba verdaderos sustos. Terminó pidiendo a las autoridades españolas, que le ayudasen para volver a España. Durante unos meses aquel cerdo con la ingenuidad alemana, y la cocina española, se hizo rico. Su tipo era mefistoéelico, alto con barbita puntiaguda. Un perfecto judio, le faltaba la estrella de David entre pecho y espalda, no nos era simpático. [Sic $]^{26}$

Como vemos, estamos ante un pequeño cuento moralizante sobre el tipo ideal de judío, un parásito social entregado al engaño y, por medio de éste, a hacer "mountains of money", una de las masas con las que según Theweleit lo identificaría el fascista alemán, junto con la de "lascivious flesh" y las "piles of corpses" 27 . El pro-

25 Citado en NÚÑEZ SEIXAS, Xosé Manoel: “¿Eran los rusos culpables?...”, p. 706. La cursiva es mía.

26 SÁNCHEZ DIANA, José María: Cabeza de puente..., pp. 86 y 179. La cursiva es mía.

27 Citado en THEWELEIT, Klaus: Male Fantasies. Volume 2..., p. 9. 


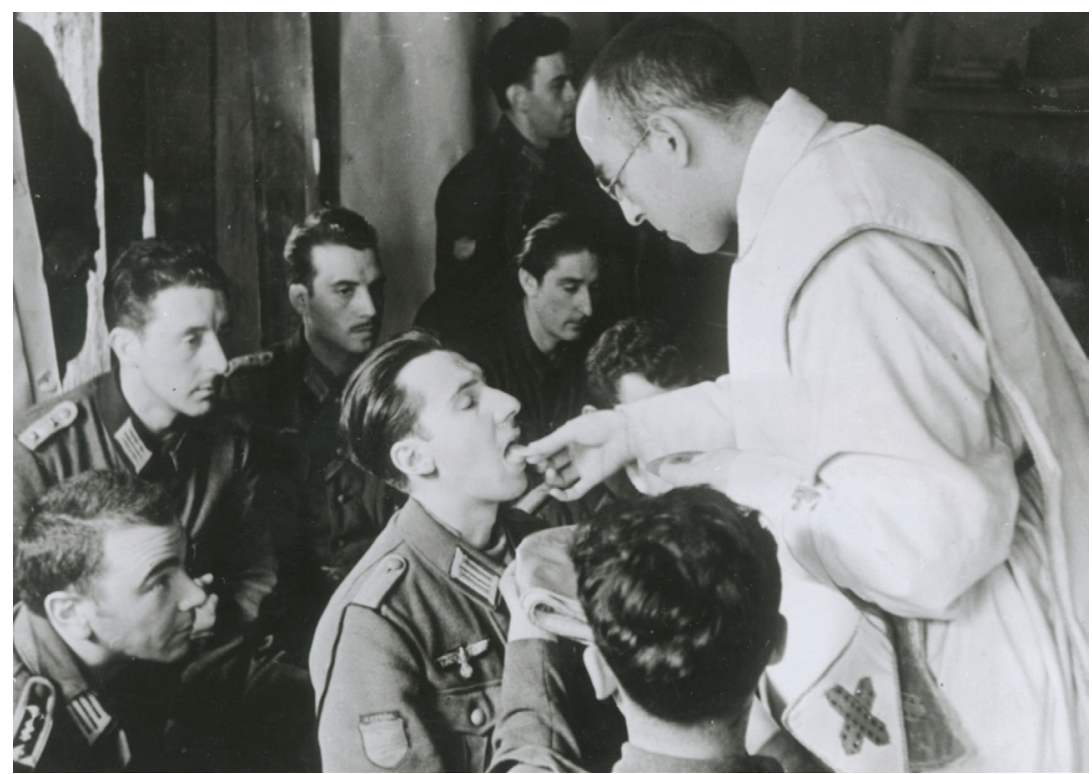

Misa de campaña. Archivo Xosé M. Núñez Seixas

pio Ridruejo va a referirse a un grupo de judíos que la División se cruzó a su paso por Radoscovice, ya en Bielorrusia, de los cuales va a afirmar que se encontraban "marcados, abatidos, con la mirada vaga. No sé de dónde ni hacia dónde", llegando a mostrar cierta repulsa por los métodos sistemáticos de marcaje y segregación de los alemanes pero justificando, eso sí, "El repentino y pasional saco, a sangre y fuego; la liquidación brutal, instantánea, explosiva; el ajuste de cuentas", que le parecían "más explicables, más aceptables." 28 Así pues, lo que no gusta no es el asesinato tanto como el hecho de su planificación, porque de algún modo, el verdadero hombresoldado responde a los estímulos propios del combate o, por qué no, del entorno inmediato, ya que es ahí donde se da la lucha por la conservación y consolidación del ego fascista, tal y como trataremos de demostrar.

\subsection{La agorafobia fascista y las oleadas de rusos que brotan de la tierra}

La conservación de la unidad y la rigidez fueron dos obsesiones recurrentes en el fascismo, un tema que ya tratamos en El fascismo como experiencia interna somatizante por medio de la teoría de la matrioskas. Dicho planteamiento vendría a complementar la tesis de Theweleit del body armor, según la cual el fascista se proveería de una coraza externa que evitaría el desbordamiento de éste a manos de sus propios impulsos emocionales y de las amenazas externas de disolución. En este sentido, lo que planteábamos es la existencia de una armadura compuesta por diversas capas que

28 Citado en REVERTE, Jorge M.: La División Azul..., pp. 133-134. 
protegerían al individuo y que, igualmente, le servirían como medio para escapar de sí mismo (de los deseos e impulsos que porta en su interior) creando espacios seguros más allá de sí mismo. Cada una de las matrioskas sería una proyección de la anterior, siendo todas iguales en forma, color y diseño, siendo la pequeña la encarnación de todas ellas a nivel del sujeto individual. De este modo, el individuo quedaría enmarcado dentro de la familia, la unidad militar, la patria, la civilización europea-cristiandad y, por último, el imperio. Así pues, es decisivo tener en cuenta que todo individuo o espacio externo que no encaje dentro del juego de matrioskas quedaría automáticamente excluido y marginado de la realidad, de modo que o bien es considerado prescindible -eliminable- o bien se intenta asimilar por los más diversos medios, teniendo la violencia un papel fundamental en ambos $\operatorname{casos}^{29}$. De este modo, lo que el fascista va a hacer en su constante huida hacia delante es tratar de hacer aprehensible el mundo, limpiar espacios externos para poder desenvolverse con seguridad, recomponer el cielo para evitar que este caiga sobre su cabeza. Nada más ilustrativo en este sentido que su cancionero, donde nos encontramos con que el Cara al sol habla de que "Formaré junto a mis compañeros/ que hacen guardia sobre los luceros,/ impasible el ademán,/ y están presentes en nuestro afán" o, por otro lado, el himno de la propia División Azul, donde se afirma que "Cielo azul/ a la estepa desde España llevaré,/ se fundirá la nieve/ al avanzar, mi capitán" o "Avanzando voy;/ para un mundo sombrío/ llevamos el sol;/ para un cielo vacío/ llevamos a Dios." Inmediatamente varias cosas nos llaman la atención en estas letras, cuyo análisis nos servirá para avanzar un paso más en nuestros análisis. En primer lugar, observamos las constantes referencias al cielo, que responderían a una necesidad primordial del fascista dirigida a recomponer el dosel sagrado, hasta el punto de que el destino de los caídos sería convertirse en estrellas inmortales que servirían de guía a los vivos y contribuirían a apuntalar la cubierta celeste. De algún modo, el objetivo es la consecución de seguridad y de un sentido para la lucha. De hecho, el combatiente de la División Azul lleva a Rusia consigo su cielo sanado por los fuegos y la sangre de los muertos en la Guerra Civil, y lo hace tanto en un sentido civilizatorio como por una mera necesidad de supervivencia psíquica: necesita hacer reconocible el lugar donde combate, situar sus propios puntos de referencia para evitar el peligro de disolución que, como veremos, acecha a cada momento en Rusia. Así pues, el fascista lleva el cielo azul, el sol y a Dios, precisamente para iluminar ese espacio tenebroso y disolvente que es la estepa, para penetrar la oscuridad de los bosques, para fundir el manto de nieve que, como en una pesadilla, lo pone ante la evidencia de su propio abismo interno. Y, como trataremos de mostrar más adelante, la dinámica es avanzar, constantemente, huir hacia delante, salir de sí mismo, aprehender y hacer seguros nuevos espacios, expandir esa armadura de la que hablábamos antes.

Por lo tanto, como decíamos, para el fascista la estepa va a aparecer como una suerte de mar de inmensa vastedad, dominada por los bosques, la nieve, el barro y los pantanos que la cubren, en proceso de cambio constante, lo cual para el fascista, que ansía la permanencia, se torna terrorífico e insoportable. De algún modo, el paisaje

29 Para profundizar en estos aspectos véase ALEGRE LORENZ, David: "El fascismo como experiencia interna somatizante...”, y THEWELEIT, Klaus: Male Fantasies. Volume 1..., pp. 204-228. 
ruso causaría un vértigo tremendo en el combatiente fascista, que teme ser absorbido y disuelto por ella. Díaz de Villegas, general del Estado Mayor de la División Azul, apuntaba en este sentido que

El paisaje ruso requiere, primordialmente, párrafo aparte. Rusia es, sobre todo, la monotonía geográfica y el agobio de la inmensidad. El hombre no se siente allí el rey del medio, sino su esclavo. [...]. El horizonte recuerda al del mar. La estepa se extiende infinita; pero cuando el bosque surge no parece, tampoco, tener fin. [...]. ¡Monotonía también del suelo! [...] No encontraréis en él una sola piedra. [...]. Falta, también aquí, la "tradición hecha piedra" de nuestras catedrales, o simplemente de los grandes monumentos cívicos o militares que, desde Roma a nuestros días, es el basamento del arte arquitectónico del centro y del occidente de Europa: [...] la tradición necesita vivir del espíritu, pero se cincela en la piedra. Solovief lo dijo: La falta de piedra priva al campesino ruso del sentido de la continuidad y del esfuerzo. ${ }^{30}$

Fijando nuestra atención en otros contextos no deja de ser curioso que Díaz de Villegas compare la estepa con el mar, un espacio salvaje aún por conquistar que amenazaría con doblegar y disolver al hombre. En este caso, observamos cómo el fascista tiene la imperiosa necesidad de dominar y estructurar la vasta extensión desoladora del espacio geográfico ruso para no diluirse en él, lo cual nos muestra hasta qué punto el fascismo es un hijo bastardo de la racionalidad elevada a los altares de la civilización por la Ilustración: todo aquello que escapa a los presupuestos racionales del fascista -lo inaprehensible- provoca insoportables sensaciones físicas y psíquicas, entre ellas el vértigo del que hablábamos. Precisamente, Jonathan Littell, en su estudio de La campaña de Rusia de Leon Degrelle apunta respecto al paisaje ruso que el fascista siente que

Ese territorio hay que estructurarlo urgentemente, que cuadricularlo y rayarlo so pena de perder pie en él. [...] Esa reterritorialización (en el sentido que le da Deleuze a la palabra) incluye no sólo el espacio físico, sino también sus representaciones.

A continuación, el autor cita algunos apuntes de la obra de Degrelle:

Tan rápido era el avance, que se necesitaban a diario mapas nuevos. [...] Incluso los menores detalles los regía un orden maravilloso. [...]. Si triunfaba la Alemania Nacional Socialista, sería dueña del Este, de una prodigiosa tierra de florecimiento, pegada a su costado, unida a ella directamente por ferrocarriles, ríos y canales, abierta a su talento organizativo y productor. ${ }^{31}$

Por lo tanto, podemos observar la existencia de toda una serie de lugares comunes en el fascismo europeo como modo de ser en y ante el mundo. De hecho, esta pugna entre la naturaleza y el hombre moderno está muy presente en la obra de Heidegger,

30 DÍAZ DE VILlEGAS, J.: La División Azul en línea, Barcelona, Editorial Acervo, 2003 (reedición), pp. 45-46.

31 LITTELL, Jonathan: Lo seco y lo húmedo. Una breve incursión en territorio fascista, Barcelona, RBA, 2009, pp. 43-44. La cursiva es mía. 
cuyo diagnóstico de la realidad de la época se nos antoja fundamental para comprender este afán reterritorializador ${ }^{32}$. De algún modo, el hombre moderno, en su constante afán por conquistar todos los aspectos de la realidad mediante la razón habría dado lugar a un mundo descreído, sin lugar para la mística y la trascendencia. Precisamente esta es la tragedia del fascismo: el hombre se convierte en esclavo de esa nueva deidad bondadosa y traicionera, la técnica, en su afán por reconfigurar el mundo y rehacerlo a su imagen y semejanza, de modo que sea un espacio seguro, familiar. Sea como fuere, Heidegger tratará de reenfocar la crisis en un sentido positivo por medio de la voluntad de poder nietzschiana como fuerza que se prueba a sí misma en el dominio y control de la realidad, del objeto, del mundo en definitiva. Ese ego que se expresa por medio de la fuerza de la voluntad a través de la técnica es el imperio de la metafísica, que alcanza su máxima capacidad de expresión como acto estético, siendo el único objetivo prevalecer. En este sentido, lo que están planteando tanto Degrelle como Díaz de Villegas es la imposibilidad del ruso para trascender por las condiciones naturales del espacio geográfico que habita, de hecho su incapacidad para permanecer o siquiera conservar la rigidez, una de las obsesiones fundamentales del fascista en su lucha contra la disolución. Visto así, Rusia sería para el fascista la encarnación misma de ese peligro de disolución, de ahí que los referentes claves de su imaginario colectivo sean pétreos y verticales. Tanto Theweleit para el caso de los Freikorps ${ }^{33}$ como Littell para el caso de Degrelle ${ }^{34}$ han destacado la importancia de este último punto, algo que curiosamente hemos observado también en Sánchez Diana, que recordaba que "Cruzamos el Rhin por un puente gigantesco y entramos en Estrasburgo, cuya torre se veía desde el tren. ¡Qué torre!" 35

Sea como fuere, lo que nos gustaría que quedara claro es esa suerte de agorafobia que el fascista siente ante lo desconocido, en este caso la geografía rusa. Sin ir más lejos, Joaquín Miralles Güill apuntaba que en una conversación con la viuda de un compañero de armas recordaba de Rusia "su dureza, su frío, el terreno que se transformaba continuamente en inhóspito, etc." 36 Precisamente como el mar, siempre igual pero en constante proceso de mutación, en este sentido algo inabarcable y desconcertante presto a estallar en cualquier momento en una inmensa tormenta. Un testimonio que apunta en la misma línea es el de Chaves Nogales, quien apuntaba que "El paisaje llega a ser desesperante. La inmensidad de Rusia es tal que ataca a los nervios. [...]. Nada. Bosques y campos de siembra sobre una planicie interminable cuya redondez se muestra netamente en la línea del horizonte." ${ }^{37}$ Algo similar se observa en el caso de Sánchez Diana, quien recoge las palabras estremecedoras de su camarada de armas Alfonso:

\footnotetext{
32 Véase FERRY, L. y RENAUT, A.: “Heidegger, el nazismo y la modernidad”. Heidegger y los modernos, Buenos Aíres-Barcelona-México, Paidós, 2001, pp. 87-106.

33 El autor alemán apunta que «The threat of the "flood" may be combated with "erections": towering cities, mountains, tropos, stalwart men, weapons.» THEWELEIT, Klaus: Male Fantasies. Volume 1..., ..., p. 402.

34 LITTELL, Jonathan: Lo seco y lo húmedo..., p. 36.

35 SÁNCHEZ DIANA, José María: Cabeza de puente..., p. 43.

36 MIRALlES GÜILL J.: Tres días de guerra y otros relatos de la División Azul, Alicante, García Hispán. Editor, 1981, p. 75.

37 Citado en REVERTE, Jorge M.: La División Azul..., p. 138. La cursiva es mía.
} 
esto es ya demasiado para una persona. Tengo a veces la impresión de que se me va a romper el espíritu. [...]. No sabíamos al apuntarnos lo que íbamos a ver. Pero ahora tenemos la vida destrozada. No podremos ser lo que fuimos, jamás. [...]... si te contara que a veces he tenido ganas de pegarme un tiro en la sien... Esto es de una desesperación única. [...]. Pero el frío y la nieve es algo que jamás borraré de mis nervios. Los llevaré toda la vida. Toda la vida tendré frío. $[\mathrm{Sic}]^{38}$

De algún modo, lo que el autor está mostrando son los traumas derivados de la experiencia de combate, pero también la tragedia del fascista, que acentúa la crisis interna y externa que pretendía resolver al poner de manifiesto en su constante huida violenta hacia delante su incapacidad para sobreponerse al abismo que porta dentro de sí y que amenaza con desbordarlo. En cierto sentido, esos desoladores paisajes rusos pusieron a muchos frente a sí mismos. Precisamente por eso, el mismo Sánchez Diana llega a reconocer que

durante días, para nosotros, no había otro horizonte que el bosque. Un bosque virgen en el que no había penetrado el hacha ni el pie, ni el fuego. Cerrado a toda civilización. ¿A dónde vamos hoy?... al bosque. Y la orden nos hiere. [...]. Pero el bosque nos ponía la piel de gallina. Sensibilizábamos hasta tal punto nuestros sentidos que yo creo, inventábamos algo nuevo. Pues junto al oído, el tacto, el olfato, la mirada, poníamos odio contra aquella naturaleza latente y extraña que oprimía por todos lados. Además, sentíamos una enorme sensación de inferioridad. ${ }^{39}$

Llegados a este punto estamos ante una cuestión esencial para la comprensión de los miedos del combatiente de la División Azul y su visión del enemigo. En buena medida, el pavor que causa en éste el paisaje ruso -fundamentalmente su carácter inhóspito, salvaje y cambiante- tiene que ver con el hecho de que el soldado ruso, observado a menudo como un fluido en sí mismo, se confunde con el terreno hasta el punto de que parece brotar de la tierra, lo cual lo hace doblemente amenazador. No por nada, Theweleit apunta que para los combatientes de los Freikorps "Bolshevism seems to be a kind of ocean that surges onward in waves, inundating and engulfing.", así señala algunos testimonios que hablan de que "The Reds inundated the land", "the raging Polish torrent", "The stream of insurgents pours" o "This was where the water gushed thogh its ribs and plates" ${ }^{40}$. En este sentido, esa idea de la amenaza comunista -siempre asociada con el ruso o Rusia, como ya señalábamos- aparece constantemente asociada a la tierra, al acecho, presta a saltar en el momento adecuado, tal y como señala Núñez Seixas en uno de los testimonios que recoge: "al otro lado del Wolchow se erguía «Asía, agazapada en odio y muerte tras el emblema sangriento de su estrella de cinco puntas»." ${ }^{41}$ Testimonio que es doblemente importante por tres motivos: la animalización del enemigo, su personificación como Asia y, por lo tanto, su exclusión de la civilización europea, algo que también hacía Díaz de Villegas al excluir a Rusia por la carencia de una tradición forjada en piedra. Lo que vemos es

\footnotetext{
38 SÁNCHEZ DIANA, José María: Cabeza de puente..., pp. 196-197. La cursiva es mía.

39 SÁNCHEZ DIANA, José María: Cabeza de puente..., p. 133. La cursiva es mía.

40 Citado en THEWELEIT, Klaus: Male Fantasies. Volume 1..., p. 229.

41 Citado en NÚÑEZ SEIXAS, Xosé Manoel: “Eran los rusos culpables?...”, p. 725.
} 
cómo constantemente se están poniendo en marcha potentes mecanismos de inclusión-exclusión que contribuyen a favorecer procesos de desempatización y aportan instrumentos ideológicos para legitimar los excesos propios de una guerra total. En esta línea merece la pena traer a colación el testimonio de Sánchez Diana, siempre tan plástico en el tratamiento de sus experiencias psicosomáticas de guerra: "Los bosques rodean las posiciones de los españoles. Entre puesto y puesto, hay masas de árboles y plantas que nos dejan aislados. Son nubes posadas a ras de la tierra, hoscas y sombrías respirando odio." Es sorprendente ver hasta qué punto el fascista dota de vida propia a la naturaleza, en medio de la cual él aparece junto a sus camaradas como una isla que trata de mantenerse a salvo del peligro de disolución, porque

Los encuentros con los rusos son mortales. La lucha aquí es como un combate de lobos. [...]. Los bosques están infestados de rusos. Las bandas luchan sostenidas por la población civil. Las noticias hablan de traiciones, de sorpresas, y entonces de represalias. [...]. Y lo peor no es solo eso, el rodear dando vueltas y vueltas al mismo objetivo, sino el hundimiento en los pozos y hoyos falsos. No sé donde leí una vez que el bosque sugería a Dios. ¿Qué sabría de esto ese escritor?, el bosque sugiere solo al demonio. ${ }^{42}$

En este fragmento, Sánchez Diana nos muestra el grado de exposición constante al que se encuentra sometido el soldado fascista (población civil hostil, naturaleza inaprehensible, el propio combatiente ruso), rodeado de amenazas que se extienden de forma epidémica y bajo riesgo constante de disolución, lo cual lo mantiene en un estado de tensión y rigidez permanente; así pues, el soldado opta por la violencia como modo de relacionarse con el entorno y como medio para huir de su propio miedo. El mismo autor da una muestra de hasta qué punto el combatiente ruso se identifica con la tierra - de la cual brota como por ensalmo en sucesivas oleadas- al afirmar tras una acción de combate cuerpo a cuerpo con el enemigo que "Dos figuras se retuercen en el suelo... «Otets mat...» o algo así dicen. Se les remata y no vemos más que un montón de trapos viejos terrosos." ${ }^{43}$ Este testimonio es clave para comprender la psicología y visión del enemigo por parte del fascista por dos motivos: en primer lugar porque muestra la deshumanización del ruso, que pierde todo contorno definido, $y$, en segundo lugar, porque nos muestra su incapacidad para conservar la rigidez, siendo su estado natural la disolución y su ecosistema ese inquietante paisaje ruso, con el cual se confunde. Así pues, el fascista mata para la conservación y consolidación de su ego, es decir, para sobrevivir, pero no ya sólo en un sentido físico, sino también trascendente, porque lo que pretende justamente es sobreponerse a ese peligro de disolución representado por el ruso, que viene a ser paisaje, comunismo y judaísmo al mismo tiempo.

42 SÁNCHEZ DIANA, José María: Cabeza de puente..., p. 132.

43 SÁNCHEZ DIANA, José María: Cabeza de puente..., p. 108. La cursiva es mía. 


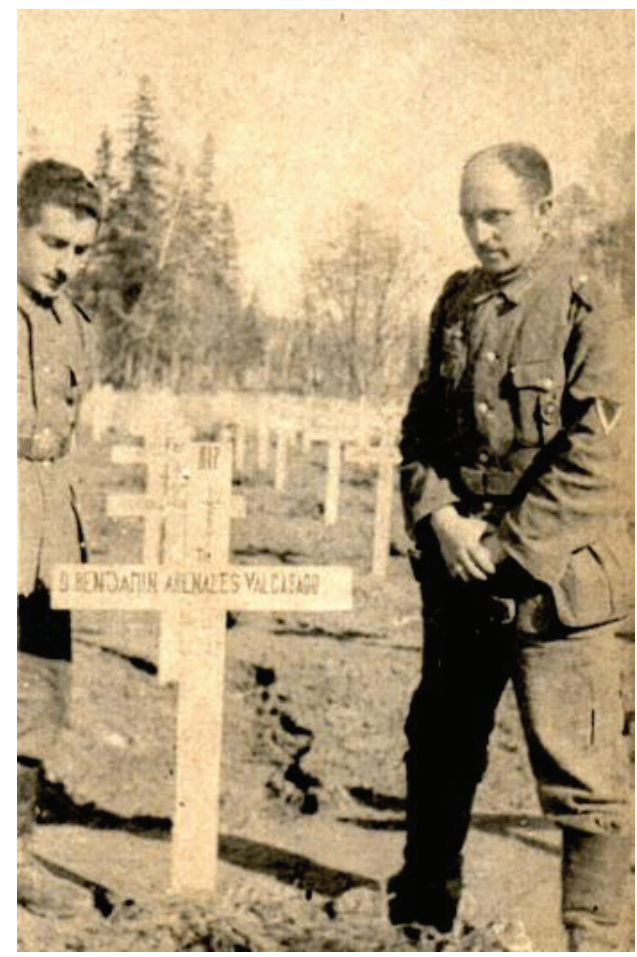

División Azul. Cruz. Archivo Rodríguez Jiménez

1.3. Otros peligros y amenazas: el abismo interno del ego fascista, la retaguardia como espacio de disolución, el traidor y el cobarde

Como venimos apuntando a lo largo del trabajo, el combatiente fascista se ve sometido a una constante sensación de cerco, a lo cual no sólo contribuyen sus enemigos - los rusos o lo ruso propiamente dicho-, sino su misma naturaleza humana y todo lo que ha dejado a sus espaldas, una dimensión fundamental de su visión de la realidad. El fascista es en sí mismo una amenaza para él, precisamente por ese abismo que porta en su interior, lo cual tiene que ver en no poca medida con su incapacidad para establecer una relación de normalidad entre su ámbito interno (es decir, el subconsciente y los impulsos generados por éste, así como sus propias sensaciones y sentimientos) y la realidad exterior. Esto es así hasta el punto de que ambas dimensiones llegan a solaparse, dando lugar a una visión distorsionada donde todo cobra unos contornos difusos y, por lo tanto, amenazadores. Theweleit se planteaba si acaso, bajo las condiciones extremas propias del combate, el individuo no confundiría sus propias proyecciones internas o marcos de referencia con el ámbito externo de la realidad, es decir, si no se produce una fusión entre los ámbitos psíquico y físico percibidos por el combatiente.

De algún modo, el individuo trata de mantener el control sobre sí mismo en una situación de gran tensión que siente lo desborda, tanto desde el exterior como desde 
sus mismas entrañas, teniendo la sensación de que al mismo tiempo que la tierra se abre en medio de la lluvia de acero él mismo sufre una brecha por la que se deshace en forma de miedos y sentimientos. Tal y como plantea en el testimonio de un paramilitar de los Freikorps

Right beneath the visible world, the immensity of the unfathomable begins: a numbly glowing, fluid ocean of ebbings and floods, of incalculable forces of pressure and tension. ${ }^{44}$

Una vez más, la solución para salvar esa situación crítica es esa armadura externa, ese juego de matrioskas o body armor fabricado de represión y disciplina, un dique personal que conjura las amenazas que tratan de convertir en polvo al individuo. Precisamente, la escritura es uno de los medios empleados por el fascista para restañar esa armadura que precisa de refuerzos constantes. En este sentido, como planteábamos, el fascista tiene miedo de sí mismo, de sus propios sentimientos y temores por el simple hecho de que amenazan con disolver la rigidez necesaria para cumplir con su deber y, al mismo tiempo, para hacer posible su propia supervivencia. Justamente esto es lo que llevó a Sánchez Diana a reflexionar en los siguientes términos respecto al momento en que el tren con destino a Alemania partía de Madrid:

Sentí durante unos momentos la ausencia de la familia como un dolor físico. Tardé en reponerme. Pero desde entonces he procurado huir de las emociones. La taquicardia emotiva nunca es buena. Es mejor rehuirlas, pasar de largo, escaparse por la tangente. Unas líneas escritas pueden hacer el mismo efecto y surtir mejor provecho. [...]. No es esconder el ala, sino sencillamente economizar sentimientos, lo que para un carácter apasionado es necesario. En algunos momentos siempre encuentro la fórmula: "Muchacho, esto es demasiado serio para reírte y tu demasiado hombre para llorar..." $[\mathrm{Sic}]^{45}$

En este punto podemos constatar las reacciones psicosomáticas sufridas por el autor en el momento de la partida, refiriendo sensaciones cercanas a la ansiedad que serían salvadas por medio de la rigidez y de la huida hacia delante, al tiempo que señala la escritura como medio para evacuar el barullo de impulsos internos contenidos. Justamente por ello el fascista entiende que "No hay nada más espantoso que ver llorar a un hombre." ${ }^{46}$ De hecho, es el propio Sánchez Diana quien nos muestra con su testimonio hasta qué punto se ajusta a la realidad la idea de body armor-lejos de ser un mero concepto historiográfico para el análisis y comprensión de la realidadcomo sostén de la existencia del fascista, al menos tal y como lo percibe y siente éste:

Tu camarada es un hombre como tu, pero nunca te dirá lo que siente por vergüenza, esa vergüenza que calla las expresiones [...]. Son como caracolas que guardan en su interior la música de lo profundo, o de nuestra tierra, [...]. Salíamos con los hombres

44 Citado en THEWELEIT, Klaus: Male Fantasies. Volume 1..., ..., p. 240.

45 SÁNCHEZ DIANA, José María, Cabeza de puente..., p. 30.

46 SÁNCHEZ DIANA, José María: Cabeza de puente..., p. 210. 
de otras épocas a otros ríos y a otros países. Era un pedazo de España el que llevábamos pero también nosotros lo éramos en nuestra dimensión. ${ }^{47}$

Esa vergüenza de la que habla es el precario equilibrio sobre el que se sostiene la estructura psíquica del fascista, la piedra de toque de su universo interno, porque el mismo reconocimiento del miedo y los sentimientos puede suponer su deriva y, por lo tanto, su misma perdición. En este sentido, es significativa la metáfora de la caracola, ya que ante la percepción de una amenaza el fascista puede introducirse dentro de su cáscara y resistir los embates externos e internos. De algún modo, esa cáscara sería la representación del juego de matrioskas que compondría la armadura física con que se protege el fascista, ya que éste se ve a sí mismo como una pequeña encarnación microscópica de la comunidad nacional, de España. De igual forma, por más que sea algo en lo que no podemos profundizar ahora merece la pena apuntar que nos muestra el mito de la palingenesia como uno de los ejes rectores de la experiencia fascista, que supondría la integración del glorioso pasado nacional en un presente moderno donde se potenciarían las virtudes del individuo como parte de la historia y, al mismo tiempo, último eslabón de la comunidad nacional ${ }^{48}$. Al fin y al cabo, dicho contribuye decisivamente a favorecer el ser en el tiempo del sujeto individual y, por lo tanto, a superar el miedo a la anomia, uno de los abismos que porta dentro de sí el fascista.

Sea como fuere, otra dimensión clave de los temores y amenazas que acechan al fascista es la retaguardia, algo que se observa en gran variedad de contextos y casos bajo las más diversas formas. De algún modo, aquello que está a la espalda del soldado configura una dimensión negativa, de forma que la retaguardia es entendida como un espacio de disolución siempre relacionado con la idea de "puñalada por la espalda" elaborada en Alemania al calor de los sucesos de 1918-191949. No hay duda de que está plenamente arraigada esa idea de que mientras en el frente se consumen y mueren los mejores, en la retaguardia los débiles, traidores y cobardes cobran ventaja desenvolviéndose con facilidad ${ }^{50}$. En este sentido, Miguel Ezquerra da cuenta de su sentimiento de culpabilidad durante un periodo en que estuvo trabajando en la retaguardia en actividades de contraespionaje:

Durante el tiempo que permanecí en París llevé una existencia frívola y peligrosa. [...], visitaba el París nocturno. Vivíamos en un ambiente de difusa moralidad, al margen de la familia y de aquellos camaradas que con tanta generosidad y gallardía entregan sus vidas en el campo de batalla. Nuestro proceder no podía ser más lamentable. ¡Era la guerra!.

47 SÁNCHEZ DIANA, José María: Cabeza de puente..., p. 41.

48 Encontramos múltiples referencias en Sánchez Diana: "Son momentos éstos donde el ojo histórico el más sencillo soldado ve toda una época girar y volver el pasado a existir. Un poco de sensibilidad que se tenga y la gran fuerza del ayer nos atenaza el corazón.”. Ídem, p. 87. Otro ejemplo interesante lo aporta Miguel Ezquerra al referir su experiencia previa a la Segunda Guerra Mundial durante la Guerra Civil española: "La ibérica Huesca [...]. Con la braveza acumulada durante siglos, en las horas de dramática duda de julio de 1936, optó por el alzamiento militar.” EZQUERRA, Miguel: Berlín, a vida o muerte, Granada, García Hispán, 1999 (cuarta edición), p. 9.

49 El ejército español tuvo su particular visión de esta idea debido al rechazo masivo de la sociedad a la guerra colonial de Marruecos.

50 Para el caso alemán véase THEWELEIT, Klaus: Male Fantasies. Volume 1..., pp. 395-397. 
Sin embargo, el mismo autor expresa su visión de la realidad de un modo mucho más plástico en un fragmento donde muestra el espacio de retaguardia como un inmenso prostíbulo situado bajo el subsuelo, de forma que amenazaría los mismos cimientos de la realidad, lo cual no hace sino poner de manifiesto con gran intensidad uno de los principales temores del fascista: perder pie en el mundo. Así, mientras se está dirimiendo en la superficie la batalla de Berlín, en el sótano del hotel Kaiserhof

seguían imperando el lujo y la artificiosidad, al servicio de los últimos diplomáticos y periodistas extranjeros y de algunas cocottes internacionales. Estas últimas, muy guapas, muy bien vestidas, nos miraban con insistencia, sonrientes, pensando tal vez que buscábamos "el reposo del guerrero". ${ }^{51}$

En este punto, el autor está poniendo de manifiesto la traición inherente al hecho de vivir de espaldas a la realidad en el momento en que se está dirimiendo poco menos que el destino de la humanidad, mostrando además una imagen subversiva de la mujer -encarnación en sí misma de la retaguardia-, que con sus cantos de sirena trata de distraer al héroe de su deber ${ }^{52}$.

El propio Sánchez Diana nos muestra la relación directa entre el propio espacio de la retaguardia, el cobarde y el traidor, considerados ambos agentes subversivos y disolventes que ponen en riesgo la obra del combatiente en el campo de batalla, conseguida a costa de su sudor y su sangre. Así pues, refiriéndose a una conversación tenida en un tren hospital con otros heridos afirma que

Nuestro pensamiento era que la juventud combatiente, al volver a España, impondría sus deseos políticos, la reforma agraria y la destrucción del capitalismo. [...] engañaron y sorprendieron los listos de siempre, que se quedaron en la retaguardia y hasta les quitaron la novia. [...] durante unas horas fuimos felices arreglando España y creyendo sinceramente en nuestra empresa. Si nos engañaron, peor para los engañadores. Nosotros resultamos más buenos y ejemplares que ellos. ${ }^{53}$

En cierto sentido, no puede sorprendernos este modo de pensar, más aún si tenemos en cuenta que muchos de los voluntarios de la primera leva actuaron movidos no sólo por la fe en sus planteamientos ideológicos, sino como parte de una firme apuesta política en pos de la legitimidad, que habría de ser conquistada por las armas ${ }^{54}$. Esta sensación de agravio se vio potenciada por el hecho de que muchas remesas de voluntarios fueron ninguneadas por las autoridades al regresar a España, encontrándose con que otros ocupaban de forma permanente cargos que hasta su partida habían desempeñado ellos. Sea como fuere, el lenguaje empleado para referirse a los que permanecieron en la retaguardia es agresivo y despreciativo: "ratas", "gusanos",

51 EZQUERRA, Miguel: Berlín, a vida o muerte..., pp. 35 y 76.

52 En la misma página se refiere a una de ellas como "prostituta de lujo".

53 SÁNCHEZ DIANA, José María: Cabeza de puente..., p. 158.

54 Desde nuestro punto de vista esta fue una motivación clave para hombres como Ridruejo o Sotomayor a la hora de decidir su alistamiento en la División Azul. Volver a España con la vitola de héroes conquistadores era demasiado jugoso, más teniendo en cuenta que se esperaba una guerra rápida y fácil. 
"bandidos", "camuflados", "esbirros", "vividores y pancistas" 55 , "pusilánime", "traidores", "degenerado y porcino" ${ }^{56}$. Sin lugar a dudas, lo que se pone de manifiesto son potentes mecanismos de inclusión-exclusión que vendrían a reflejar un intento por consolidar, definir y restañar el ego fascista maltrecho por la derrota -no olvidemos que trabajamos con relatos escritos a posteriori-, para la cual buscarían una explicación, siendo parte de ella la influencia subversiva de la retaguardia.

\section{El derribo de las misteriosas puertas de lo imposible o la huida hacia delante}

Tanto a la izquierda como a la derecha hubo millones de personas que se vieron incapaces de sustraerse a la fascinación de participar en la fundación de un nuevo mundo y, de algún modo, sentir la experiencia extrema de estar pariéndolo. Para muchos se trataba de dar un salto más allá, de empujar desde lo más hondo de las entrañas para dar inicio a una nueva temporalidad fundada por la experiencia de la violencia, que vendría a marcar una cesura radical en el modo de entender el mundo. Precisamente, todo esto daría lugar a la fundación de un nuevo código moral mediante la conciencia y la confianza de estar en posesión de los valores absolutos por antonomasia, lo cual legitimaba al despliegue de la brutalidad más absoluta como acto de fe: la marcha a la guerra o las privaciones más draconianas, entendidas como sacrificio purgativo. Sin embargo, muchos cobraron conciencia de la imposibilidad de llevar a buen término sus propuestas utópicas para la transformación integral de la realidad. De algún modo, penetrar la coraza de los seres humanos haciéndolos sentir y vivir las cosas de un modo concreto había sido un fracaso, pues había un punto insuperable, una barrera insalvable que hacía imposible ir más allá. En ese momento, muchos vieron la tragedia que habían contribuido a poner en marcha en su intento por devolver al mundo una fe auténtica, algo que no se encontrara hollado por la razón, que conservara su misticismo original más allá del peso asfixiante de la modernidad. Como decíamos, seres humanos de todo tipo entregaron en mayor o menor medida sus vidas al fascismo, creyendo que allí encontrarían la solución a una profunda crisis espiritual que se vivía en clave de quiebra absoluta y paralizante. Había entre ellos gran cantidad de intelectuales que abrazaron el fascismo sugestionados por el canto de sirena del modernismo y la palingenesia, convencidos de que aquel era el camino y el fin, incapaces de ver más allá de una fachada y un espíritu que en realidad no eran más que la encarnación de una constante huida hacia delante, un intento por escapar del vórtice que la crisis había abierto en el seno de cada uno de ellos. No obstante, su intento por restituir aquella fe había producido un desgarro aún mayor que aquel con el que se encontraron en un primer momento y al cual pretendían poner solución. Roger Griffin nos cuenta cómo ya herido de muerte al volver del frente ruso, el representante del experimentalismo racionalista Giuseppe Terragni tomó conciencia del monstruo que había contribuido a poner en marcha con su apoyo. ${ }^{57}$ De algún modo, todos esperaban el alborear de una nueva era alumbrada por aquella violencia, que se veía como

55 EZQUERRA, Miguel: Berlín, a vida o muerte ..., pp. 45, 64, 65, 74, 91, 109, 126.

56 LUCA DE TENA, Torcuato: Embajador en el infierno ..., pp. 49, 50, 67.

57 GRIFFIN, Roger: Modernismo y fascismo..., p. 345. 
un elemento purificador necesario, un acto estético de fe que trascendería el mismo tejido del espacio-tiempo, un hecho que por sí mismo haría historia.

Como siempre, Sánchez Diana ofrece una buena muestra de cómo sentían los fascistas lo que ocurría a su alrededor y, al mismo tiempo, cómo entendían sus propios actos. En su marcha hacia el frente central, donde había sido destinada la División Azul en un primer momento, el autor recuerda que un domingo en que

el Pater al rezarnos la misa [...]. Improvisó la plática, dedicada a la grandeza de la guerra y como su contacto nos acercaba a Dios. Le oímos conmovidos... [...] "con los pies podéis hacer la Historia lo mismo que los panzer y que esos cañones gigantescos. Tenéis sangre y nervios y la historia se hace también con hombres. ¡No solo de motores y de gasolina! También el HOMBRE, con mayúsculas, juega su papel, el principal y encima de él, está Dios". [Sic ${ }^{58}$

La Iglesia católica, un elemento fundamental en la configuración de la conciencia e identidad fascistas en España, al dar una dimensión mística a la guerra, ordenadora del universo y marco propiciatorio donde se produce la forja del auténtico hombre fascista, marcado a sangre y fuego por la violencia. En este sentido, el discurso del sacerdote resulta interesante, pues nos muestra al fascista como hacedor de la historia, con el pecho y la espalda como muros de contención y los pies como las rígidas y firmes raíces que lo agarran a la tierra, que reterritorializa y consolida con su violencia convertida en acto de fe. Pero una y otra vez se hace evidente el hecho de que cada gota de sangre derramada, cada cuerpo sin vida acrecienta la brecha que amenaza con arrastrarlo todo. Sin embargo, el fascista siente que "Los campos se abren paso a paso. Lo que se deja a la espalda, ya no es, solo existe en papel apuntado. [...]. Seguir sin mirar atrás, adelante, sin recuerdos ni tiempo para ellos" ${ }^{59}$, porque parar significa el fin, ya que el fascismo es una apuesta del todo por el todo, un inmenso Moloch que una vez se ha desatado exige un tributo cada vez mayor en vidas. Precisamente, Sánchez Diana llega a decir que "Nuestra psicología de hombres de guerra, disfruta solo con el ansia de matar." ${ }^{60}$ Ese abismo interno del que huye el fascista es sentido por el mismo autor de forma psicosomática, refiriéndose a él en pleno combate como "Vacío en el estómago." ${ }^{61}$ De hecho, el fascista no puede evitar sentir la experiencia mística inherente a sus actos, y por un momento cree observar el mundo con total claridad:

Estoy asombrado de la lucidez que hay ahora en mi mente, las emociones de la víspera, me han dejado insensible y no extraño nada. [...]. Estamos poseídos de una firme locura, jurando y dando "Arribas España". Choco contra un cuerpo al que he metido la bayoneta. La sangre resbala por los dedos. He de apoyar el cuerpo en esa masa y tirar hacia arriba para sacar la hoja. No sé que cara tenía. Todo se hace entre gritos, [...]. Entramos en las casas del pueblo, que es una calle larguísima. Las registramos, si hay algún soldado enemigo dentro se le mata. Se entregan algunos pero la gente de la com-

58 SÁNCHEZ DIANA, José María: Cabeza de puente..., pp. 88-89.

59 SÁNCHEZ DIANA, José María: Cabeza de puente..., p. 90.

60 SÁNCHEZ DIANA, José María: Cabeza de puente..., p. 147.

61 SÁNCHEZ DIANA, José María: Cabeza de puente..., p. 107. 
pañía excitada, los fusila en el acto sin oírles. [...], yo estoy emperrado en coger a dos tipos que corren.. [...] Y vuelvo a buscar a un tipo que se esconde entre los corrales. El pobre tiene un miedo atroz. Mi insistencia es ya de tonto, por fin le tiro una bomba de piña. Da un brinco y se queda quieto, tras una nubecilla a ras de suelo. Me lo he cargado, entonces, sin aliento, me siento... ${ }^{62}$

En esos instantes, en mitad del fulgor del combate, todo parece cobrar sentido, pues el abismo interno es proyectado hacia el exterior, contra el enemigo, y el ego fascista se reafirma en la violencia y la muerte del otro, que ha perdido por completo sus contornos, de forma que sólo es aprehensible por medio de la bayoneta. La pugna del fascista pasa a ser una pugna por salir indemne en la medida de lo posible, por conservar la rigidez y la integridad de su ser, para lo cual apela a la trascendencia suprema de sus actos. De algún modo, el combatiente se ve a sí mismo como un Moisés que abre las aguas con su particular acto de fe, en este caso la acción violenta, la muerte, que abre el camino y aproxima el horizonte.

Ya la paz y la tranquilidad no tienen sentido para nosotros. Los amigos muertos se olvidan. Las caras entrañables las vemos un momento y luego desaparecen. Nos hundimos en la lucha sin reflexionar. La naturaleza bárbara que nos rodea, está ya vencida por nuestra propia barbarie. La guerra nos consuela de una vida pasada hasta ahora estúpidamente y tenemos a España muy cerca del corazón. ${ }^{63}$

Una vez más, el fascista apela a la trascendencia, a esa capa de su armadura que identifica con la patria y que se convierte en la piedra de toque de su rigidez. Llegados a este punto es imposible pensar en la posibilidad de una marcha atrás, porque el mismo fascista ha destruido el camino de vuelta. Ahí, en esa huida hacia delante, en la muerte convertida en acto de fe es donde se produce la afirmación del ego, el fortalecimiento de la armadura externa del fascista, y en ese momento siente que se eleva por encima de todo lo demás y se pone en contacto íntimo con la que cree su esencia.

Las furias del ser animal brotan con un despliegue gigantesco de vitalidades únicas. La Fé en uno mismo, crece con la muerte. Y el espiritu se transforma en algo áspero, espinoso, duro. [...]. La grandeza de la virilidad ante la propia muerte nos roza con un aleteo trágico y deslumbrante, descubriendo el auténtico ser que llevamos dentro. $[\mathrm{Sic}]^{64}$

Justamente, como apuntaba el autor en la cita de más arriba, es la voluntad de poder encarnada en el acto violento -elevado a acto estético mediante el uso del lenguaje- lo que hace posible la conquista de esa realidad salvaje y difusa, ese mundo hostil de contornos amenazadores que aparece ante el fascista y, al mismo tiempo, le permite por un momento escapar de sí mismo.

62 SÁNCHEZ DIANA, José María: Cabeza de puente..., p. 110.

63 SÁNCHEZ DIANA, José María: ..., p. 150. La cursiva es mía.

64 SÁNCHEZ DIANA, José María: Cabeza de puente..., p. 129. 


\section{Conclusiones. El fascismo: una utopía quijotesca}

El hecho de que atribuyamos un espíritu quijotesco al fascismo no implica ningún tipo de nostalgia romántica, sino más bien todo lo contrario: denota una inmensa tragedia, como lo hace la obra de Cervantes. Una diferencia básica que hemos podido observar entre el viejo hidalgo y los combatientes fascistas radica, por un lado, en el hecho de que al primero nadie salvo su escudero lo tomó nunca en serio, mientras que, por el otro, los segundos son hijos de un tiempo en que las sociedades europeas sintieron vivir una situación de crisis liminoide, en palabras de Griffin. De hecho, no deja de ser significativo que durante una parada de la marcha a pie de la División Azul hacia el Frente del Este, los compañeros de Sánchez Diana sacaran a colación con deleite un texto de Unamuno que algo más de diez años antes habría llamado la atención de Ramiro Ledesma Ramos. El texto de 1908 decía que

Hay que contestar con insultos, con pedradas, con gritos de pasión, con botes de lanza. No hay que razonar con ellos. Si tratas de razonar frente a sus razones, estás perdido. [...]. Que tus palabras sean estridentes y agrias a sus oídos. [...] Y, ante todo, cúrate de una afección terrible que, por mucho que te la sacudas, vuelve a ti con terquedad de mosca: cúrate de la afección de preocuparte cómo aparezcas a los demás. ${ }^{65}$

De algún modo, el terror generado por aquella sensación de cambio permanente llevó en muchas ocasiones a optar por salidas radicales, tal y como plantea Unamuno en su texto -lo cual explicaría cómo en un primer momento pudo llegar a mostrar cierta connivencia con los golpistas-, porque sólo algo radical y revolucionario parecía ofrecer una solución para un impasse de tales características.

Frente al diletantismo y las palabras el fascista abogaba por la acción. "El fascista se propone literalmente «hacer historia». [...] relacionada [...] con la sensación creciente de nuevo comienzo." ${ }^{66}$ Muchos creyeron que la vía más radical y revolucionaria para la fundación de ese nuevo tiempo era la violencia, que de algún modo conseguiría dar a luz una tabula rasa sobre la que reconfigurar la realidad en su totalidad. Y el hecho de que decenas de miles de fascistas de todo el continente creyeron haber hecho historia lo demuestra la necesidad perentoria de escribir que mostraron después de la guerra, todo ello con el fin de dejar constancia de su fe y sus ideales, de su obra revolucionaria y su noble impulso redentor. En este sentido, Teodoro Palacios deja clara esa idiosincrasia al apuntar, respecto a su bagaje vital en los años 30 , que «De estudiante deseé la paz sin rehuir la guerra. Más tarde, en España, hice la guerra por conseguir la paz.» ${ }^{67}$ De tal forma que nos encontramos con que en su diálogo consigo mismo y con la realidad exterior el fascista siempre se acaba encontrando con la violencia, que se acaba convirtiendo en medio y fin al mismo tiempo. Llegados a este punto no podría estar más de acuerdo con Paxton en el hecho de que la singularidad

65 Citado en LEDESMA RAMOS, Ramiro: “Grandezas de Unamuno”. La Conquista del Estado, 21 de marzo de 1931, n 2, p. 1.

66 GRIFFIN, Roger: Modernismo y fascismo..., ..., p. 255.

67 LUCA DE TENA, Torcuato: Embajador en el infierno, ..., p. 40. 


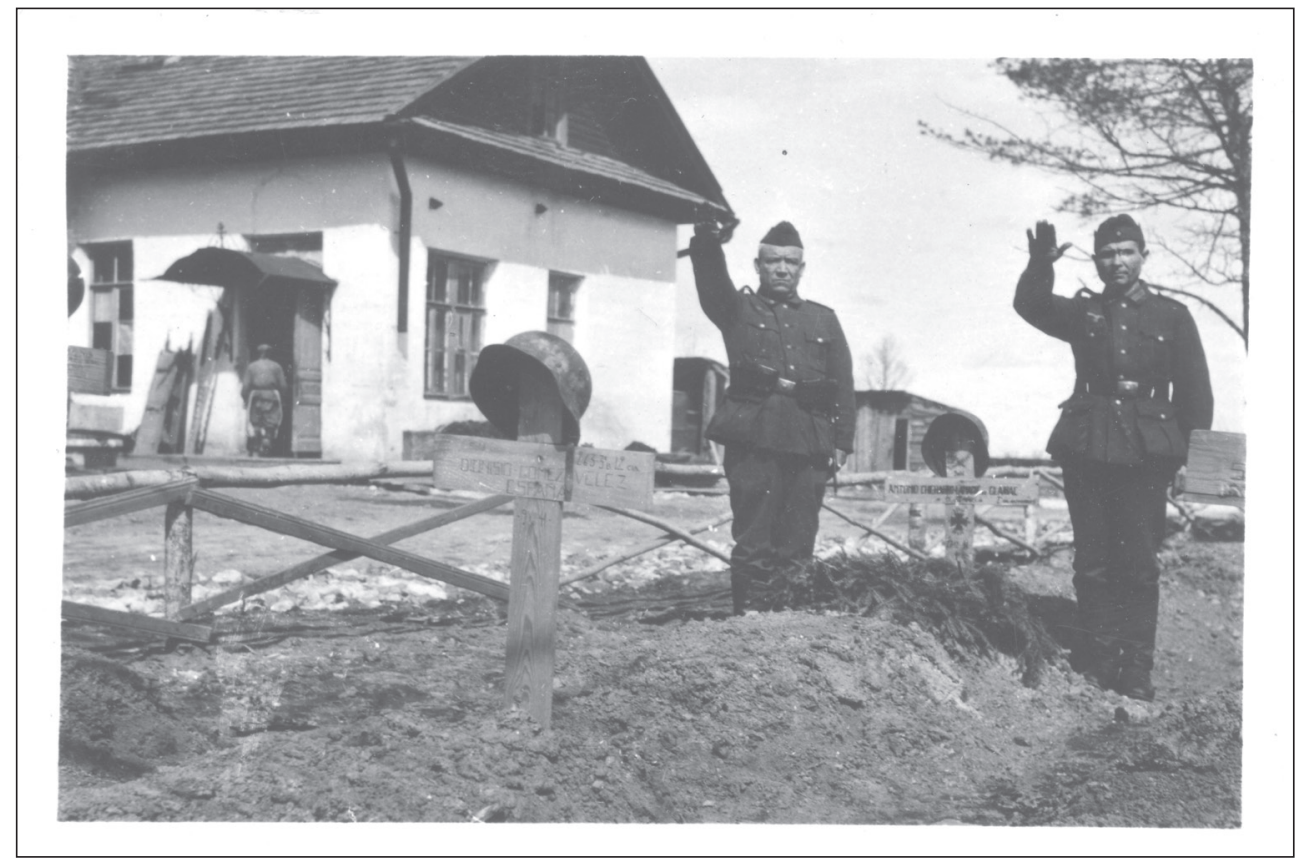

Las bajas, allí quedaron. Archivo Rodríguez Jiménez

del fascismo reside en esa violencia que lo lleva a huir de sí mismo y, por tanto, en su consubstancialidad a la guerra. ${ }^{68}$

Algunos como Giuseppe Terragni se dieron cuenta de lo que habían ayudado a desencadenar, otros como Sánchez Diana, Miguel Ezquerra, Teodoro Palacios, Miralles Güill o Díaz de Villegas vivieron hasta el final de sus días creyendo en la conveniencia y necesidad de sus actos. Sin embargo, todos ellos sintieron la necesidad de revisitar su pasado y escribir como forma de canalizar la angustia y el dolor inmenso producido por la derrota. De algún modo, el objetivo era "coser y desgarrar, conservar y arrojar" o, si se quiere, restañar el maltrecho ego en una inmensa operación de salvamento, todo ello con el fin de adecuar su historia a las exigencias del océano desbordante que llevaban dentro de sí mismos y del mundo en constante estado de disolución que les rodeaba. No por nada, "Fue una tarde mirando al mar, en la soledad de la playa, cuando vinieron con enorme fuerza a mí los recuerdos. Sí, tomé la decisión de escribir estas páginas, páginas doloridas, después de meditar ante el mar $[\ldots][\text { Sic }]^{\prime \prime 69}$.

68 PAXTON, Robert O.: Anatomía del fascismo, ..., pp. 198-201.

69 SÁNCHEZ DIANA, José María: Cabeza de puente, ..., p. 15. 


\section{Bibliografía}

ALEGRE LORENZ, David: "El fascismo como experiencia interna somatizante: una propuesta de análisis del fascismo español a través del lenguaje", en Miguel Ángel RUÍZ CARNICER (ed.): Falange. Las culturas politicas del fascismo en la España de Franco, Zaragoza, PUZ e IFC, 2012, en prensas.

ALONSO IBARRA, Miguel: "Identidad y alteridad en la Guerra Civil. La experiencia de combate como medio de socialización de elementos identitarios y culturales del fascismo español". Actas del III Congreso Interdisciplinar de Jóvenes Historiadores: Historia, Identidad y Alteridad, en prensas.

CHICHARRO LAMAMIÉ DE CLAIRAC, J.: Diario de un antitanquista en la División Azul, Madrid, Fundación División Azul, 2001.

DÍAZ DE VILLEGAS, J.: La División Azul en línea, Barcelona, Editorial Acervo, 2003 (reedición).

EZQUERRA, Miguel: Berlín a vida o muerte, Granada, García Hispán, 1999 (cuarta edición).

FERRY, L. y RENAUT, A.: "Heidegger, el nazismo y la modernidad". Heidegger y los modernos, Buenos Aíres-Barcelona-México, Paidós, 2001.

GRIFFIN, Roger: Modernismo y fascismo. La sensación de comienzo bajo Mussolini y Hitler, Madrid, Akal, 2010.

JULIÁ, Santos: "Las nombres de la guerra", Claves de razón práctica, 164 (2006).

KOVACSIS, Adan: Guerra y lenguaje, Barcelona, Acantilado, 2007.

LITTELL, Jonathan: Lo seco y lo húmedo. Una breve incursión en territorio fascista, Barcelona, RBA, 2009.

LUCA DE TENA, Torcuato: Embajador en el infierno, Barcelona, Planeta, 1991.

MIRALLES GÜILL J.: Tres días de guerra y otros relatos de la División Azul, Alicante, García Hispán. Editor, 1981

NÚÑEZ SEIXAS, Xosé Manoel: "El Tercer Reich, la Wehrmacht y la División Azul”. Ayer, 69 (2008), pp. 47-72.

NÚÑEZ SEIXAS, Xosé Manoel: “¿Eran los rusos culpables? Imagen del enemigo y políticas de ocupación de la División Azul en el Frente del Este, 1941-1944". Hispania. Revista Española de Historia, 223 (2006), vol. LXVI, pp. 695-750.

NÚÑEZ SEIXAS, Xosé Manoel: “¿Testigos o encubridores? La División Azul y el Holocausto de los judíos europeos: entre historia y memoria". Historia y Política, 26 (2011).

PAXTON, Robert O.: Anatomía del fascismo, Barcelona, Península, 2005.

REVERTE, Jorge M.: La División Azul. Rusia, 1941-1944, Barcelona, RBA, 2011.

RODRIGO, Javier: "A este lado del bisturí. Guerra, fascistización y cultura falangista”, en Miguel Ángel RUÍZ CARNICER (ed.): Falange. Las culturas politicas del fascismo en la España de Franco, Zaragoza, PUZ e IFC, en prensas. 
RODRIGO, Javier: Hasta la raiz. Violencia durante la Guerra Civil y la dictadura franquista, Madrid, Alianza, 2008.

RODRIGO, Javier: "Violencia y fascistización en la España sublevada", en Francisco MORENTE: España en la crisis europea de entreguerras, Madrid, Los Libros de la Catarata, 2011.

SÁNCHEZ DIANA, José María: Cabeza de puente. Diario de un soldado de Hitler, Alicante, García Hispán Editor, 1990.

THEWELEIT, Klaus: Male Fantasies. Volume 1: Women, Floods, Bodies, History, Minneapolis, University of Minnesota Press, 2007 (sexta edición).

THEWELEIT, Klaus: Male Fantasies. Volume 2 Male Bodies: Psychoanalyzing the White Terror, Minneapolis, University of Minnesota Press, 1989.

VETRONE, Angelo: "Hombre, animal, cosa, polvo. La violencia contra el enemigo político en perspectiva histórica" en Jordi CANAL y Eduardo GONZÁLEZ CALLEJA: Guerras civiles. Una clave para entender la Europa de los siglos XIX y XX, Madrid, Casa de Velázquez, 2012. 